\title{
Local Communication, Local Understanding Effectiveness of Climate Reporting by TV Weathercasters
}

Adapted from "Localized Climate Reporting by TV Weathercasters Enhances Public Understanding of Climate Change as a Local Problem: Evidence from a Randomized Controlled Experiment," by Irina Feygina (Climate Central, Inc.), Teresa Myers, Bernadette Placky, Sean Sublette, Tammie Souza, John Toohey-Morales, and Edward Maibach. Published online in $B A M S$, July 2020. For the full, citable article, see DOI:10.1175 /BAMS-D-19-0079.1.

 he most successful public communication about climate change tends to feature simple, clear messages, repeated often by a variety of trusted sources. Toward this end, the AMS encourages weathercasters to be "station scientists" who educate the public about local climate change impacts. However, a 2010 nationwide survey showed that few weathercasters were participating due to lack of time and resources.

The Climate Matters program was designed to address this. It was developed as a local resource program enlisting and enabling TV weathercasters as local, trusted, science-based, nonpolitical climate educators. The programpilot tested in 2010-11 by George Mason University, Climate Central, and WLTX (in Columbia, South Carolina), and offered nationwide in 2013 by Climate Central, George Mason University, AMS, NOAA, and NASA-provides weekly, TVready information about local impacts of climate change using high-quality graphics and locally relevant and timely information. Consequently, on-air reporting about climate change increased dramatically between 2012 and 2018, though evaluation of efficacy has been limited. 
We set out to rigorously test the efficacy of Climate Matters materials in a randomized, controlled experiment. First, we investigated whether watching a local TV weathercaster report on the link between climate change and weather led to greater acceptance of and concern about climate change. Furthermore, a key goal of the Climate Matters program is to reach diverse audiences, demographically and ideologically. Conservative audiences tend to be exposed to messages from political and social authorities disparaging scientific evidence about climate change, thereby potentially counteracting efforts to communicate the science. So, we also investigated whether viewing localized climate reporting by a TV weathercaster affected people across the political spectrum in the same way.

\section{Methods}

We recruited 1,200 participants from the Chicago and Miami media markets, via an online survey company (Qualtrics). Recruitment quotas ensured a balance of demographics and political ideology. Two local TV weathercasters (one from each market) who participate in the Climate Matters program each created three 1-2-minute videos in which they discuss climate change in the context of their local weather. The participants were randomly assigned to watch the weathercaster from their market deliver either three weather segments (control condition) or three weather segments linking climate change to their local weather (experimental condition).

For Chicago, the first video linked the trend in increasing temperature there to climate change and the increase in global average temperatures. The second video discussed heavy rainfall and flooding, and linked it to global temperature rise. The third video included part of a conversation with James Hansen about how climate change and record average global temperatures are impacting temperatures in Chicago. For Miami, the first video addressed how climate change is contributing to the increasing temperature trend and record summer heat and extreme weather in south Florida. The second video discussed an increase in heavy rainfall events in Florida and linked this to climate change. The third video covered the king tide and increasing flooding, and discussed how climate change is making this more severe due to sea level rise and is exacerbating its impacts.

For the control condition, we selected existing videos that matched, to the extent possible, the same types of weather-a heat wave, rain and a cold spell, and heat and humidity conditions in the summer in Chicago, and for Miami, heat and a dry spell, rain along the coast and in the Florida Keys, and a stretch of hot summer days.

Participants were asked about their levels of acceptance, perceived proximity and relevance, and concern regarding climate change, and willingness to take action in mitigating and adapting to its effects, before and after watching the weathercasters.

\section{Results}

Watching localized climate videos, compared to weather videos, consistently led viewers to greater acceptance of anthropogenic climate change as a legitimate threat, a stronger sense of its proximity and relevance, and increased concern about its impacts. Additionally, participants expressed greater interest in learning more about the topic and strategies to limit climate change and mitigate its harmful impacts. The climate videos increased perceived efficacy around mitigation, but not adaptation-a difference that warrants further investigation. Importantly, the climate videos were similarly effective for participants across the ideological spectrum. While conservative respondents tended to be less likely than liberal respondents to accept, be concerned about, and be engaged with climate change, watching climate videos increased their acceptance of and concern about climate change as much as for liberal respondents. In sum, climate videos increased acceptance of, concern about, and engagement with climate change regardless of participants' political orientation.

\section{Discussion}

These findings suggest that climate education via trusted local communicators, specifically weathercasters, is an effective way to connect with audiences who may not be receiving accurate or compelling climate information in other ways. They also provide clear evidence that the Climate Matters approach is effective in increasing awareness of climate change among the general public. Corroborated by other research, the findings offer the most 
direct causal proof that exposure to climate coverage within weather reports is an effective communication tool. This study demonstrates the effectiveness of the materials and the approach used by a rapidly increasing number of TV weathercasters participating in the Climate Matters program in engaging diverse audiences with the issue of climate change.

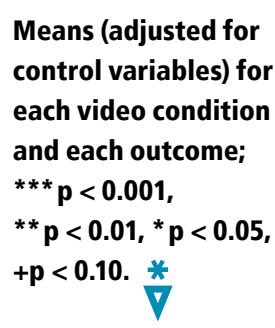

The study also points to questions for future investigation. For instance, it is important to note that the two selected media markets differed in several ways. Participants in Miami seemed to know more about climate change and reacted more strongly to the videos, possibly because they are already seeing climate change impacts, such as sea

\begin{tabular}{|c|c|c|c|c|}
\hline \multirow[b]{2}{*}{ Question } & \multirow[b]{2}{*}{ Response options } & \multicolumn{2}{|c|}{ Mean } & \multirow[b]{2}{*}{$\begin{array}{c}\text { Mean } \\
\text { difference }\end{array}$} \\
\hline & & Weather & $\begin{array}{l}\text { Climate } \\
\text { Matters }\end{array}$ & \\
\hline $\begin{array}{l}\text { Do you think climate change is a bad thing } \\
\text { or a good thing? }\end{array}$ & $(1=$ very bad; 11 = very good $)$ & 5.50 & 4.77 & $-0.73^{* * *}$ \\
\hline $\begin{array}{l}\text { Do you think that climate change is } \\
\text { happening or not? }\end{array}$ & $\begin{array}{l}\text { ( } 1=\text { I am certain climate change is not } \\
\text { happening; } 11=I \text { am certain climate } \\
\text { change is happening) }\end{array}$ & 8.91 & 9.24 & $0.33^{*}$ \\
\hline $\begin{array}{l}\text { To what extent do you think climate change } \\
\text { over the past } 100 \text { years is caused by natural } \\
\text { events or by } \\
\text { human activities? }\end{array}$ & $\begin{array}{l}(1=\text { Completely by natural events; } \\
11 \text { = Completely by human events) }\end{array}$ & 8.05 & 8.28 & $0.23+$ \\
\hline $\begin{array}{l}\text { How well do you feel you understand how } \\
\text { climate change works? }\end{array}$ & (1 = Not at all; 11 = Extremely well) & 7.80 & 8.38 & $0.58^{* * *}$ \\
\hline $\begin{array}{l}\text { To what extent is climate change personally } \\
\text { relevant to you? }\end{array}$ & $\begin{array}{l}(1=\text { Not at all personally relevant; } \\
11=\text { Extremely personally relevant })\end{array}$ & 8.00 & 8.36 & $0.36^{*}$ \\
\hline How concerned are you about climate change? & $\begin{array}{l}(1=\text { Not at all concerned; } \\
11=\text { Extremely concerned })\end{array}$ & 8.12 & 8.57 & $0.45^{* *}$ \\
\hline $\begin{array}{l}\text { When, if ever, do you think climate change } \\
\text { will start } \\
\text { to make the weather worse in your community? }\end{array}$ & $\begin{array}{l}(0=\text { Now, it is already happening; } \\
100=100 \text { years from now })\end{array}$ & 39.17 & 34.43 & $-4.74^{*}$ \\
\hline $\begin{array}{l}\text { How much do you think climate change will } \\
\text { harm people in your community? }\end{array}$ & $\begin{array}{l}(1=\text { Will not harm at all; } \\
11=\text { Will harm extremely })\end{array}$ & 7.33 & 7.78 & $0.45^{* *}$ \\
\hline I want to learn more about climate change. & $\begin{array}{l}(1 \text { = Strongly disagree; } \\
11 \text { = Strongly agree) }\end{array}$ & 8.08 & 8.35 & $0.27+$ \\
\hline $\begin{array}{l}\text { I want to learn more about ways to protect } \\
\text { myself from the impacts of climate change. }\end{array}$ & $\begin{array}{l}(1 \text { = Strongly disagree; } \\
11 \text { = Strongly agree) }\end{array}$ & 8.01 & 8.29 & $0.28+$ \\
\hline $\begin{array}{l}\text { I want to learn more about ways to limit } \\
\text { climate change. }\end{array}$ & $\begin{array}{l}(1=\text { Strongly disagree; } \\
11=\text { Strongly agree })\end{array}$ & 8.05 & 8.33 & $0.28+$ \\
\hline $\begin{array}{l}\text { I believe I can reduce my risk of being } \\
\text { harmed by climate change. }\end{array}$ & $\begin{array}{l}(1 \text { = Strongly disagree; } \\
11 \text { = Strongly agree) }\end{array}$ & 7.10 & 7.28 & 0.18 \\
\hline $\begin{array}{l}\text { I believe I can contribute to limiting } \\
\text { climate change. }\end{array}$ & $\begin{array}{l}(1=\text { Strongly disagree; } \\
11 \text { = Strongly agree })\end{array}$ & 7.46 & 7.77 & $0.31^{*}$ \\
\hline
\end{tabular}


level changes. Conversely, in Chicago, cold and snowy winters may somewhat blunt awareness of and concern about climate change. Future research would do well to include areas that are predominantly rural in their sample, as well as other regions of the United States. Another future direction is to investigate the extent to which weathercaster attributes, such as gender, age, etc., play a role in a communicator's perceived credibility, and how this may differ among media markets.

In sum, this study provides strong and consistent evidence that providing climate information via trusted communicators in local media is an effective approach to increasing acceptance of, concern about, and engagement with climate change.

\section{METADATA}

BAMS: What would you like readers to learn from this article?

Irina Feygina (Climate Central, Inc.): Learning about climate change from local TV meteorologists is an effective way to enhance people's understanding, acceptance, and concern about climate issues across the political spectrum.

BAMS: Why is it important for TV meteorologists to do climate reporting?

IF: It is vital for the public to learn about important science issues from the media. But more and more, people are exposed to media sources that either lack the capacity to cover science, or do so in a biased, slanted way. It is also a challenge to cover this global, seemingly abstract topic in a way that improves understanding of its local impacts and relevance, and helps to prepare for what's ahead. That's why Climate Matters, the program we focus on in this article, is such an exciting initiative. It engages local weathercasters, who are trusted by their diverse audiences, to share information about climate change in a way that helps viewers draw on their experiences of the weather and make sense of changes they may be observing.

BAMS: How then, did this study of the efficacy of Climate Matters arise?
IF: As the program has grown to include weathercasters from all across the United States, it was really important to make sure-using a rigorous research approach-our climate reports are effective in communicating about climate change to the full diversity of viewers whom we are reaching.

BAMS: What surprised you the most about the work you document in this article?

IF: The most surprising, and relieving, finding was that communication by local weathercasters about climate change was equally effective for people across the political spectrum. We know from extensive prior research that, overall, being more conservative is related to being less accepting and engaged with climate change, and there are important identity-related and ideological reasons that underlie these differences. We were concerned that, as a result, our conservative participants may experience backlash to watching the climate reports we shared with them. Yet, our fears were unsubstantiated. Rather, we saw clear evidence of similar acceptance of climate information offered by TV weathercasters among participants across the political spectrum. Conservative, as well as liberal, viewers became more aware of, concerned about, and willing to take action to ameliorate climate change, as well as to continue learning about the topic.

BAMS: What was the biggest challenge you encountered while doing this work?

IF: A key challenge in our study was making sure that we used a representative sample, which included the full diversity of viewers who tune in to local weather reporting. This was particularly important because the Climate Matters program is committed to reaching audiences who may not otherwise have a chance to learn about climate change. Luckily, we were able to survey people from urban, suburban, and rural areas who spanned the full spectrum of political orientation. As a result, we were able to ensure that our materials are understandable and effective for people across the political spectrum-one of the key findings in this study.

BAMS: How might your research follow up?

IF: We only studied two media markets, one in the Southeast (Miami) and one in the Midwest (Chicago). Future research would do well to include an area that is predominantly rural in its sample, as well as other regions of the United States, such as the Plains, the Southwest, and the West Coast. 